\title{
Vitamin D and assisted reproduction technologies: Vitamin D levels and frozen embryo transfer (FET).
}

\author{
Tang Quang Thai, MD, Tran Thi Thanh Thuy, MD, and Ly Thai Loc, MD \\ Department of Infertility, Hung Vuong Hospital, Ho Chi Minh City, Vietnam.
}

Background: Vitamin D status influences female reproductive and pregnancy outcomes. Vitamin D deficiency is more common in younger women and higher BMI. There is some evidence that in addition to sex steroid hormones, the classic regulators of human reproduction, vitamin $\mathrm{D}$ also modulates reproductive processes in women and men. Human and animal data suggest that low vitamin D status is associated with impaired fertility, endometriosis and polycystic ovary syndrome. Many investigators in The US and Europe now have demonstrated higher IVF pregnancy rates in vitamin $D$ replete women in comparison with deficiency and insufficiency women. The association of vitamin $D$ insufficiency and the prevalence of pregnancy. However, in the US there is an inverse relationship between vitamin $D$ levels and clinical pregnancy rates among Asian women. The object of this study is to compare the outcomes of frozen- thawed embryo transfer cycle, in a diverse groupe of Asian patients who live in Asian region, classified into three groupe, based on plasma vitamin $D$ level.

Object: comparing the outcomes of frozen - thawed embryo transfer cycle, in a diverse groupe of Asian patients who live in Asian region, classified into three groupe, based on plasma vitamin D level.

Methods: Prospective cohort study. Setting: Public Hospital in HochiMinh City, Vietnam. Patients: 124 infertile women undergoing frozen embryo transfer in Ho Chi Minh city, Vietnam. Interventions: Serum was collected on the second day of frozenthawed embryo transfer cycle and was tested for vitamin $D$ 25(OH- D). Main outcome measured: Pregnancy rates and implantation rates.

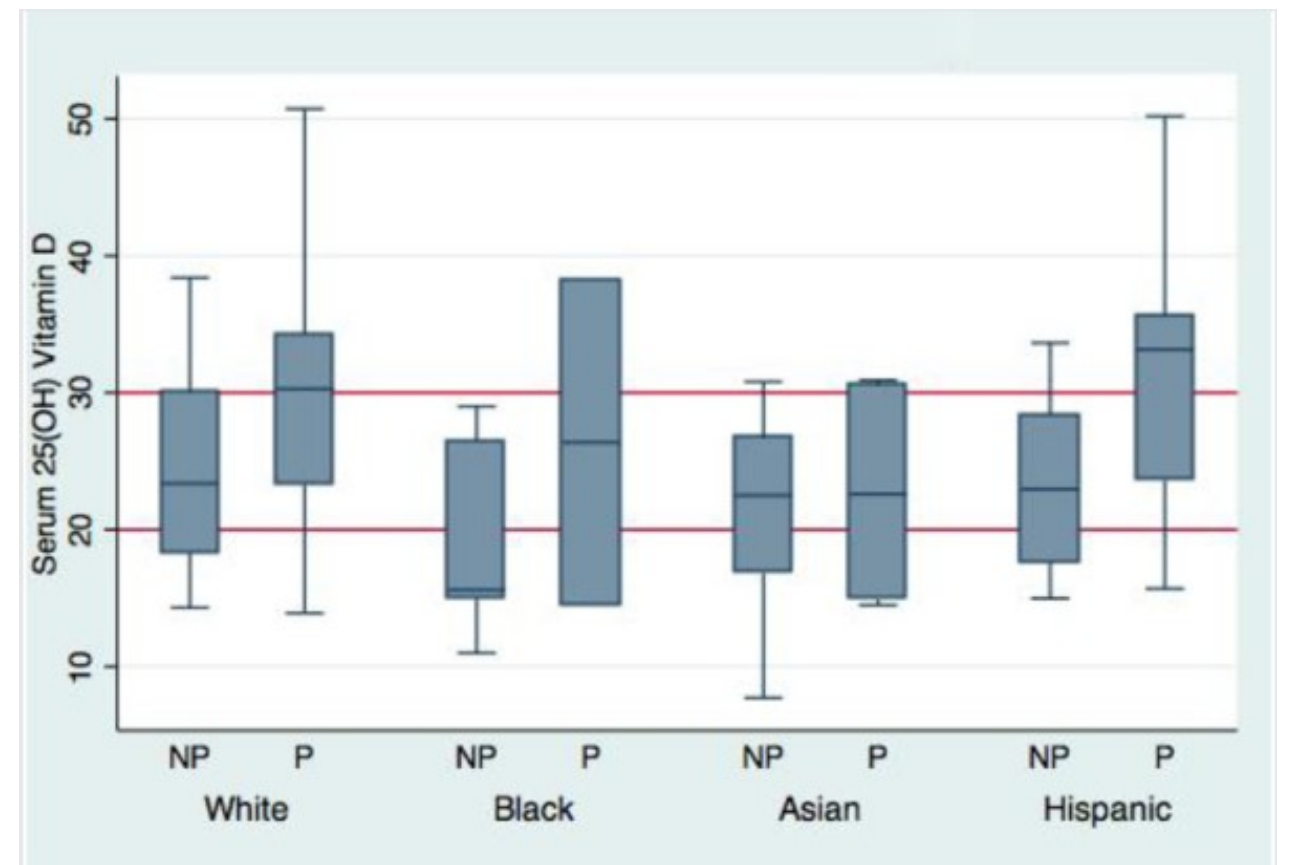

Fig. Influence of race on the relationship between recipient vitamin $D$ levels and pregnancy rates. NP not pregnant; P pregnant. - Rudick B.J et als, 2013.
Results: In 24 months, 124 patients were recruited into the study with no characteristic differences. There were no differences in clinical pregnancy rates (43.48; 49.18 and 31.58$)$ and implantation rates $(20.83 ; 22.13$; and 16.67) ( $p>0.05)$ between the deficiency, insufficiency and replete vitamin D. Our results are in concordance with those of the US studies, in which there is not an increased pregnancy and implantation rate with the increased of vitamin $D$ level (in Asian population who are living in the US).

Summary of study population characteristics.

\begin{tabular}{|c|c|c|c|c|}
\hline & $\begin{array}{l}\text { Deficiency } \\
<20 \mathrm{ng} / \mathrm{mL}\end{array}$ & $\begin{array}{l}\text { Insufficiency } \\
20-30 \mathrm{ng} / \mathrm{mL}\end{array}$ & $\begin{aligned} & \text { Replete } \\
> & 30 \mathrm{ng} / \mathrm{mL}\end{aligned}$ & $\mathbf{P}$ \\
\hline $\mathbf{N}$ & 46 & 61 & 19 & \\
\hline Age & 31.24 & 30.41 & 31.21 & 0.511 \\
\hline BMI $\left(\mathrm{kg} / \mathrm{m}^{2}\right)$ & 21.2 & 20.67 & 21.59 & 0.138 \\
\hline Endometrial thickness $(\mathrm{mm})$ & 9.22 & 9.21 & 9.21 & 1 \\
\hline Number of embryos & 2.46 & 2.41 & 2.58 & 0.648 \\
\hline \multicolumn{5}{|l|}{ Quality embryos transferred } \\
\hline Number of cells in embryo & 7.07 & 7.18 & 7.04 & 0.720 \\
\hline Fragmentation rate $(\%)$ & 8.62 & 7.17 & 6.31 & 0.097 \\
\hline
\end{tabular}

Vitamin D levels and ART outcomes.

\begin{tabular}{|lcccc|}
\hline & $\begin{array}{c}\text { Deficiency } \\
<20 \mathrm{ng} / \mathrm{mL}\end{array}$ & $\begin{array}{c}\text { Insufficiency } \\
20-30 \mathrm{ng} / \mathrm{mL}\end{array}$ & $\begin{array}{c}\text { Replete } \\
>30 \mathrm{ng} / \mathrm{mL}\end{array}$ & $\mathbf{P}$ \\
\hline Clinical Pregnancy rates (\%) & 43.48 & 49.18 & 31.58 & 0.404 \\
\hline Implantation rates (\%) & 20.83 & 22.13 & 16.67 & 0.732 \\
\hline Live Birth rates (\%) & 26.09 & 37.70 & 31.58 & 0.520 \\
\hline
\end{tabular}

Conclusion: The limitations of the study, research design, insufficient sample size, assessing the pregnancy rate is influenced by multifaceted and multiple confounding variables. The current studies on Vitamin D are available in the population of Western Countries. Further research is needed, which in turn can find meaningful differences among Asians in general and Vietnamese in particular.

\section{Reference:}

- AFLATOONIAN, A., ARABJAHVANI, F., EFTEKHAR, M. \& SAYADI, M. 2014. Effect of vitamin $D$ insufficiency treatment on fertility outcomes in frozen-thawed embryo transfer cycles: A randomized clinical trial. Iranian Journal of Reproductive Medicine, 12, 595-600.

- GARBEDIAN, K., BOGGILD, M., MOODY, J. \& LIU, K. E. 2013. Effect of vitamin D status on clinical pregnancy rates following in vitro fertilization. CMAJ Open, 1 , E77-82.

- RUDICK, B. J., INGLES, S. A., CHUNG, K., STANCZYK, F. Z., PAULSON, R. J. \& BENDIKSON, K. A. 2013. Influence of vitamin D levels on in vitro fertilization outcomes in donor-recipient cycles. Fertil Steril, 101. 